Kubik, D. (2017). Kształtowanie się idei narodu na ziemiach słoweńskich - zarys wybranych problemów. Slavia Meridionalis, 17. https://doi.org/10.11649/sm.1340

\title{
Damian Kubik
}

Instytut Filologii Słowiańskiej

Uniwersytet Jagielloński w Krakowie

\section{Kształtowanie się idei narodu na ziemiach słoweńskich - zarys wybranych problemów ${ }^{1}$}

Idea narodu na ziemiach słoweńskich rozwijała się w specyficznych warunkach polityczno-społecznych i kulturowych, jakim podlegali w ciągu swoich dziejów Słoweńcy, nieposiadający aż do końca XX wieku własnego państwa. Reprezentując mały naród ulokowany na granicy świata germańsko-romańskiego i słowiańskiego „w trójkącie bermudzkim ludów” („v bermudskem trikotniku ljudstev“"2) (Kmecl, 2005, s. 8), najczęściej wchodzili w krąg zainteresowań większych i silniejszych nacji. Trudna historia oraz często skomplikowane relacje z ościennymi narodami nie przyczyniły się jednak do zaniku narodo-

1 Artykuł powstał w ramach projektu badawczego pt. „Idee wędrowne na słowiańskich Bałkanach (XVIII-XX w.)" sfinansowanego ze środków Narodowego Centrum Nauki, nr projektu 2014/13/B/HS2/01057. artykułu.

${ }^{2}$ Jeśli nie zaznaczono inaczej, tłumaczenie cytatów z języka słoweńskiego wykonał autor

This work was supported by a grant from National Science Centre in Poland (decision No. 2014/13/B/HS2/01057). Competing interests: no competing interests have been declared.

Publisher: Institute of Slavic Studies, Polish Academy of Sciences.

This is an Open Access article distributed under the terms of the Creative Commons Attribution 3.0 PL License (creativecommons.org/licenses/by/3.0/pl/), which permits redistribution, commercial and non-commercial, provided that the article is properly cited. (c) The Author(s) 2017. 
wej tożsamości Słoweńców, ale wręcz przeciwnie - wzmocniły poczucie ich odrębności, wyrażane w pielęgnowaniu języka i narodowej kultury.

Początki wyraźnie artykułowanej narodowej tożsamości Słoweńców sięgają drugiej połowy XVI wieku, kiedy to słoweńscy protestanci widzieli ją przede wszystkim jako językową wspólnotę. Dla tych ważnych dla kultury i świadomości słoweńskiej działaczy i ideologów Słoweńcy stanowili „zbiorowość, którą tworzy język, a nie historia” („skupnost, ki jo povezuje jezik in [še] ne zgodovina“) (Štih, 2005, s. 231) - a zatem przekonanie o istnieniu oddzielnej językowej tożsamości Słoweńców nie było rezultatem konceptu narodowego ani tym bardziej religijnego, gdyż przecież „każdy język chwali Boga“ („vsak jezik slavi Boga“) (Mandek, 2011, s. 102). Ta językowa perspektywa rozumienia narodu, bazująca na przekonaniu o istnieniu ponadregionalnej słoweńskiej wspólnoty językowej („posebne naddeželne slovenske jezikovne skupnosti“) (Mandek, 2011, s. 102) zaznaczyła swoją trwałość, gdyż obowiązywała aż do początków odrodzenia narodowego z końca XVIII wieku.

Etnonim Slovenci po raz pierwszy zapisał w 1550 roku Primož Trubar na wstępie swojego Katechizmu. Janko Kos twierdzi, że - w związku z brakiem rzetelnych dowodów świadczących o istnieniu tego pojęcia przed tym okresem - możliwa jest hipoteza, że to właśnie słoweński duchowny protestancki, a przy tym autor pierwszych drukowanych książek w języku słoweńskim, jest prekursorem jego użycia, choć sam Trubar nie do końca precyzował jego zakres i używał go w różnych znaczeniach (Kos, 1996, s. 9-10). Raz stosował go na określenie Słoweńców spoza Krainy, dla których nie było innego właściwego określenia, innym razem obejmował nim prawie wszystkich Słoweńców w dzisiejszym znaczeniu, ale używał go także jeszcze w bardzo szerokim zakresie, to znaczy na określenie bliższych i dalszych narodów słowiańskich ${ }^{3}$. Etnonim ten wówczas nie przyjął się (zamiast niego wciąż funkcjonowały przede wszystkim określenia regionalne oraz wskazujące na przynależność do Słowiańszczyzny). Tak było w przypadku Janeza Ludvika Schönlebena czy Janeza Vajkarda Valvasora, który określenie Kranjci/Krainer traktuje jako synonim Słoweńców (nieraz też mając ich za Niemców).

Dopiero po roku 1800 doszło do ostatecznego uformowania tego pojęcia (Kos, 1996, s. 9-10). Wówczas to Anton Tomaž Linhart - wychodząc od kom-

${ }^{3}$ Więcej na temat roli Primoža Trubara w procesie kształtowania tożsamości słoweńskiej oraz o jego znaczeniu dla kultury narodowej, zob. m.in.: Orožen (1986-1987, s. 36-47), Samar Brenčič (2008), Bernik (2011, s. 21-28). 
ponentu językowego - jako pierwszy dostrzegł w narodzie wspólnotę ukształtowaną na określonej historii i tym samym nadał dziejom nowe, narodowe ramy, znacznie przewyższając ich dotychczasowe regionalne wymiary. O tej poszerzonej wizji dziejów jednoczących słoweńską wspólnotę językową najlepiej świadczy jego dzieło zatytułowane Pokus zgodovine Kranjske in ostalih dežel južnih Slovanov Avstrije (1788, 1791), w którym to Linhart prezentując narodowe dzieje, sięga aż do średniowiecza, gdzie odkrywa Karantanię. Dzięki właśnie tej wizji Słoweńcy zyskali swoją własną historię, co dokonało się w czasie, gdy inne narody europejskie uważały wspólne dzieje za podstawę narodowej tożsamości. Drugim ważnym ideologiem w tym czasie był Jernej Kopitar, który w swojej gramatyce zatytułowanej Grammatik der slavischen Sprache in Krain, Kärnten und Steyermark (1809) proponując ponadregionalną normę języka literackiego, przyczynił się do zakreślenia granic wspólnoty i rozpoczął proces budowania narodowej tożsamości.

Zapoczątkowany wówczas za ich sprawą proces przezwyciężania silnej regionalizacji w obrębie słoweńskiej kultury i kształtowania samoświadomości Słoweńców, przyczynił się do tego, że uznano ich za ojców założycieli narodu słoweńskiego („očeti ustanovitelji“) (Kosi, 2008, s. 98). Wskazali oni bowiem nie tylko granice wyobrażonego jeszcze narodu, ale również stworzyli podstawy i zarysowali kierunki jego rozwoju. Zakreślona zaś przez nich narodowa wspólnota stała się dla następnych pokoleń przedmiotem uwielbienia, patriotycznych uniesień, ale także powodem i impulsem do walki w jej obronie (Kosi, 2008, s. 98).

Idee i osiągnięcia Linharta i Kopitara poczynione na polu szeroko pojętej kultury duchowej, a także w sferze kształtowania jednego narodu i jednej ojczyzny, swoje źródło miały w myśli głównie niemieckich ideologów. Szczególną rolę odegrała zwłaszcza filozofia Johanna Gottfrieda Herdera ${ }^{4}$, która przenikała na ziemie słoweńskie przede wszystkim za pośrednictwem Josefa Dobrovskiego. Wpływ niemiecki na kształtowanie się kulturowej i narodowej świadomości Słoweńców często jednak był przeceniany (np. przez Matiję Murka), na co zwracali uwagę Štefan Barbarič (1978, s. 117-124) i France Kidrič (1938, s. 349-350, 354-360).

W XIX stuleciu, zwłaszcza zaś od jego połowy, pojawiały się na ziemiach słoweńskich różnorodne programy narodowe, których znaczenie dla kształ-

4 Szerzej o wpływie i znaczeniu myśli Herdera na słoweńską kulturę, zob. Babić (2008, s. 176-182). 
tującej się tożsamości narodowej trudno przecenić. Chodzi tu zwłaszcza o program Zedinjene Slovenije, który wyrastał z żywotnej potrzeby Słoweńców w ważnym, choć trudnym dla wielu europejskich narodów roku 1848. Wówczas to dostrzeżono konieczność stworzenia jednej, ponadregionalnej wspólnoty, posługującej się jednym językiem; program przewidywał powołanie słoweńskiego państwa w ramach Austrii i wyraźnie sprzeciwiał się zjednoczeniu z Niemcami. Znaczącą rolę w powstaniu i propagowaniu zawartych w programie idei mieli Matija Majar czy Janez Bleiweis, natomiast jego sens najlepiej oddaje ówczesny apel zawarty w gazecie „Grätzer Zeitung” w dniu 22 kwietnia 1848 roku: „Zniesienie historycznego rozczłonkowania na regiony i scalenie naszego słoweńskiego terytorium według kryterium językowego w jedno państwo, a tym samym zjednoczenie nas wszystkich w jeden naród” („Ukinitev zgodovinskega razkosanja na dežele in združitev našega slovenskega ozemlja po jezikovni meji v eno deželo in $\mathrm{s}$ tem koncentracijo nas vseh $\mathrm{v}$ en narod") (Melik, 1995, s. 68).

$\mathrm{Za}$ istotny moment procesu krystalizacji narodu, rozpoczętej przez Linharta i Kopitara, następnie zaś wzbogaconego doświadczeniami Wiosny Ludów, uznać należy także rok 1853, kiedy to Peter Kozler w stworzonej przez siebie mapie (chodzi tu o znany Zemljovid Slovenske) za pośrednictwem zasięgu języka i dialektów słoweńskich ${ }^{5}$ symbolicznie ukazał zasięg narodu słoweńskiego: „Mapa ta przedstawia granice języka i narodu słoweńskiego, a także jego zasięg z naniesionymi słoweńskimi nazwami miast, targów, parafii oraz mniejszych wsi, gór i rzek“ („Ta zemljovid kaže meje jezika in naroda slovenskega in njegov svet z vpisanimi slovenskimi imeni mest, tergov, farnih in tudi manjših vasi, gor in rek“) (Bohinec, 1975, s. 13). Działalność Kozlera, jak i wcześniej wspomnianych Linharta i Kopitara, doprowadziła do ostatecznego ukształtowania idei i zasięgu narodu słoweńskiego w XIX wieku (Kosi, 2008, s. 100). Pamiętać jednak należy, że zapoczątkowany wówczas proces tworzenia ponadnarodowej tożsamości przebiegał stopniowo i nie bez przeszkód aż do I wojny światowej.

Na początku następnego stulecia w obrębie refleksji nad narodem punkt ciężkości z aspektu jego granic przesunął się na kwestię jego społecznej stratyfikacji. W 1907 roku Ivan Cankar w swojej przemowie Slovensko ljudstvo in slovenska kultura - poświęconej losowi słoweńskiej kultury duchowej i problemom słoweńskich działaczy kulturalnych - dokonał w opraciu o marksistowską

${ }^{5}$ Znaczącą rolę słoweńskiego standardu literackiego w rozwoju duchowym, ale też społeczno-politycznym tego okresu omawia w swojej książce Ivan Prijatelj (1937). 
terminologię rozróżnienia pojęć lud i naród (ljudstvo i narod) (Cankar, 1921, s. 164). Pierwszy z nich, obejmuje niższe, pracujące warstwy Słoweńców, zaś drugi zarezerwowany jest dla części mieszczaństwa, pretendującego do odgrywania reprezentatywnej roli politycznej i społecznej wśród Słoweńców. Cankar dostrzega jednak znaczny dystans pomiędzy obiema warstwami, a zwłaszcza daleko posuniętą marginalizację niższych klas. Wizję podzielonego wewnętrznie narodu ukazuje w chwytliwym retorycznie zabiegu, jaki stosuje w swojej przemowie. Przedstawia bardzo wymowną scenkę z karczmy, w której dumne elity, reprezentujące całość narodu, siedzą za suto zastawionymi stołami a lud, których przedstawiciele są brudni, z czerwonymi od pracy twarzami, znajduje się oddzielnie w sąsiedniej izbie. Jeden $\mathrm{z}$ liderów warstwy panującej prosi w pewnym momencie o zamknięcie drzwi oddzielających ich od chłopstwa i zaczyna mowę o tym, jak to naród słoweński - za sprawą swej kultury - stał się równoprawny innym narodom europejskim (Cankar, 1921, s. 164).

W okresie międzywojennym, już w momencie istnienia Królestwa Jugosławii, za sprawą zwłaszcza Josipa Vidmara rozważania nad ideą narodu weszły w kolejną istotną fazę. We wstępie do swojej książki z 1932 roku Kulturni problem slovenstva ten wybitny krytyk, eseista i tłumacz podkreślając, że zacieranie różnic pomiędzy Słoweńcami a pozostałymi narodami południowosłowiańskimi jako największe osiągnięcie ówczesnej myśli liberalnej było ogromnym błędem, zauważał, iż - jak to ujął Mitja Čander w odniesieniu do jego książki - „każdy naród posiada specyficzną strukturę duchową będącą - nieważne, czy się ją wychwala, czy też się jej przeciwstawia - genotypem każdej jednostki” (Čander, 2004, s. 8). Komentator myśli Vidmara pisał dalej, że „naród jest niejako pierwszą i najwyższą instancją, jego głos jest głosem niewidzialnego Boga” (Čander, 2004, s. 9). Vidmar w myśl ówczesnej retoryki „słoweńską niezależność argumentuje pokrewieństwem i wspólnym pochodzeniem wszystkich tych, którzy uważają się za Słoweńców" (Čander, 2004, s. 9). Zdaniem Mitji Čandera „jego utopia, charakterystyczna dla małych wspólnot, to »nowe Ateny«, »nowa Florencja«, kraj wysoko rozwiniętej kultury i duchowości. My, Słoweńcy, mamy niepowtarzalną okazję przejąć od sławnych poprzedników nieprzemijające światło historii" (Čander, 2004, s. 8-9).

Przeciwko niektórym tezom zawartym w książce Vidmara wystąpił w 1932 roku w czasopiśmie „Ljubljanski zvon” Oton Župančič, oponując wobec „plačljivosti (koju) proglašavaju našom karakterističnom osobinom” („płaczliwości, [którą] ogłasza się naszą charakterystyczną właściwością") (Matvejević, 1986, s. 78). Wyrokował przy tym także, że aktywni obrońcy „naszego wewnętrznego 
slovenaštva" sprowadzą naród na manowce, doprowadzając go do samotności, zacietrzewienia i jałowości (Matvejević, 1986, s. 78). Nie wydaje się jednak, by Vidmar diametralnie zmienił swoje poglądy, o czym może świadczyć jego znacznie późniejsza wypowiedź. Otóż w 1984 roku podczas dyskusji w Czarnogórze na temat współczesnego patriotyzmu Vidmar wyznał, że Słoweńcy są najtragiczniejszym narodem w Europie, czym wzbudził niemało kontrowersji. Nie zgadzał się z tą opinią, jak również z innymi poglądami Vidmara, zwłaszcza Predrag Matvejević (Matvejević, 1986, s. 73-79).

Do podjętego przez Cankara problemu wyzysku klasy pracującej i jej decydującej roli w narodzie nawiązywał - bezpośrednio zresztą się na niego powołując - Edvard Kardelj (Razvoj slovenskega narodnega vprašanja, 1939). Jak podkreśla „historia Słoweńców jest swoistym długim łańcuchem ucisku i ciemiężenia małego narodu” („zgodovina Slovencev je ena sama dolga veriga zatiranja in teptanja malega naroda") (Kardelj, 1984, s. 19). Słoweński naród w duchu marksistowskiej ideologii był - jego zdaniem - zawłaszczony przez klasy wyzyskujące lud pracujący, co powodowało, że w obszarach, w których powinien następować postęp i rozwój, obecne było tylko opóźnienie. Tymczasem właśnie klasa pracująca jest właściwym nosicielem postępu, a także w jej łonie przechowywane są „pozytywne tradycje słoweńskiego narodu” („pozitivne tradicije slovenskega naroda“) (Kardelj, 1984, s. 26), jego kultura i wewnętrzne bogactwo duchowe. Będąc wiodącą siłą narodu, klasa ta broni interesów całego narodu i całej ojczyzny (Kardelj, 1984, s. 26). Kardelj podkreśla także znaczenie Jugosławii dla istnienia Słoweńców jako narodu, gdyż właśnie wspólne państwo gwarantuje im obronę i bezpieczeństwo narodowej tożsamości oraz umożliwia dalszy rozwój. Ten, kto by chciał szukać takich gwarancji dla narodu słoweńskiego gdzie indziej - przestrzega - schodzi na złą drogę.

W tym samym okresie Ivan Urbančič w wielu artykułach poświęconych kwestii narodu (Elementi za razvitje vprašanja naroda na Slovenskem, 1979), jak i w nieco późniejszej (z 1981 roku) monografii Uvod v vprašanje naroda, podejmuje refleksję ukazującą tę kategorię w nowych warunkach, czyli w czasach - jak sam to nazywa - „nowej konstelacji narodu we współczesnym świecie” („nove konstelacije naroda v modernem svetu“) (Urbančič, 1979, s. 83). Dokonując swoistej rekapitulacji dotychczasowych badań słoweńskich badaczy w tym zakresie, zauważa, że zdecydowana ich większość traktuje naród jako „wytartą oczywistość” („obrabljena samoumevnost“) (Urbančič, 1979, s. 84), której nie trzeba na nowo definiować, gdyż kolejna definicja nic nowego do dyskusji nie wniesie. Analizowane przez Urbančiča teorie - jak zauważa - kształtowały 
się na marginesie europejskiej myśli w tej kwestii, więc niemożliwe stało się zbadanie genezy słoweńskiego narodu (poprzez poszukiwanie tych elementów historycznych, ekonomicznych, politycznych i kulturowych, które wskazałyby powód jego powstania), jak również dziejów zmagań o jego wolność i prawo do samostanowienia. Przydając tym koncepcjom epitet "moderno-znanstvene“, stwierdza, że pojęcia lud, naród i narodowość będące pustymi słowami, nieodnoszącymi się do realnych desygnatów, stają się zwykłymi fikcjami, które nie pozwalają i nie pomagają rozwiązywać żadnych problemów związanych z życiem polityczno-społecznym:

Tak więc »lud «, »naród«, »narodowość« itd. są tylko słowami, które za sprawą sugestywnego oddziaływania języka otrzymują jedynie formę rzeczywistych desygnatów, są zatem tylko fikcją, która nie pozwala na rozwiązywanie żadnych problemów i która nie zapewnia jasnych zasad dla państwowego lub społecznego funkcjonowania.

Tako so »ljudstvo«, »narod«, »narodnost« itd. le besede, ki iz sugestivnega učinka jezika dobijo samo videz realnih entitet, so torej samo fikcije, s katerimi ni mogoče reševati kakih problemov, in ki tudi ne dajejo kakih jasnih pravil za državno ali družbeno življenje (Urbančič, 1979, s. 84).

Punktem wyjścia do własnych rozważań nad ideą narodu uczynił - najbardziej według niego zasadne - rozwiązania zaproponowane na gruncie niemieckiej filozofii idealistycznej. Ośrodkiem tej myśli była kategoria rzeczywistości, dlatego też naród rozumiany jest jako „ruch nieprzerwanej aktywności” („gibanje nenehne aktivnosti“) (Urbančič, 1979, s. 85). Dalej dodaje: „Ten ruch skutkuje lub przynajmniej prowadzi nieuchronnie do ustanowienia siebie jako własnego państwa narodowego ze swoim wewnętrznym uporządkowaniem”. („To gibanje rezultira oz. vsaj nujno teži k ustanovitvi sebe kot lastne narodne države s svojskim notranjim ustrojem“) (Urbančič, 1979, s. 85). Tezę tę Urbančič podtrzyma również w późniejszych (1997) pracach, poświęconych tej problematyce, wskazując na model Georga Wilhelma Friedricha Hegla, który widzi w narodzie/ludzie przede wszystkim kategorię kulturową, a jego duch ujawnia się w państwie. W swoich rozważaniach dochodzi w końcu do pryncypiów filozofii marksistowskiej, którą uważa za adekwatną do współczesnych mu czasów. Myśl ta odrzuca naród jako najwyższą formę organizacji człowieka, uważając ją za relikt przeszłości, typowy dla minionej (przednowoczesnej) epoki. Kolejnym etapem organizacji życia jednostki jest uniwersalne, ponadnarodowe człowieczeństwo (Urbančič, 1979, s. 87-90).

W czasie, gdy rodzimi przedstawiciele myśli socjalistycznej rozważali przede wszystkim klasowy kształt narodu słoweńskiego i jego status w konstelacji 
narodów Jugosławii, Primož Kozak z perspektywy krótkiego, jednorocznego doświadczenia pobytu w USA w zbiorze esejów zatytułowanym Peter Klepec $v$ Ameriki (1971) prezentuje przemyślenia o końcu cywilizacji naznaczonej odejściem od indywidualności i nacjonalności na rzecz obcości i globalności. Dostrzegając skostniałość i ospałość słoweńskiego społeczeństwa i stawiając za wzór otwartość społeczeństwa amerykańskiego, zauważa - nie mogąc dokonać rozrachunku z pojęciem uniwersalności i domu - że to właśnie niewielkie wspólnoty najszybciej zaczną funkcjonować jako społeczeństwa otwarte. Odrzuca zatem w jakiejś mierze logikę kolektywizmu ideologicznego i propaguje zamiast niej nacjonalizm jako formę świadomości ogółu; innymi słowy, próbuje forsować identyfikację narodową jako formę walki z poczuciem samotności w świecie konsumpcyjnym (Čander, 2004, s. 9):

Nie wystarczy, że będziemy otwarci, gdy nadal trwamy w swojej zatwardziałości; nie wystarczy, że będziemy kosmopolitami, jeżeli upieramy się bezmyślnie przy swojej odrębności; nie wystarczy, że będziemy tworzyć nowoczesne instytucje, jeśli chronimy wszystkie dziwaczne i niegospodarne przejawy naszej autochtoniczności; nie wystarczy, że będziemy starać się iść z duchem czasu, podczas gdy uparcie nawiązujemy do naszej historii. Będziemy tym, czym chcieliśmy być, co nam zgotował los - dziwacznym, zdeformowanym tworem - Słoweńcami (Kozak, 1971, cyt. za: Čander, 2004, s. 9).

Zdaniem Kozaka konstytutywną właściwością narodu słoweńskiego jest antagonizm kulturowego i politycznego boju, które się wzajemnie wykluczają. Kultura w Słowenii była od zawsze formą kontemplacji i refleksji, podczas gdy polityka wiązała się z akcją i działaniem. Dlatego też ukształtowanie narodu słoweńskiego wynika z kulturowej świadomości (w tym także autorytetu narodowych proroków) i wiodących politycznych tradycji (Kozak, 1971, s. 10).

Za zagrożenie dla małego narodu, jakim są Słoweńcy, którzy stale oscylują między kontemplacją a akcją, między autorytetami a demokratycznością, uznaje współczesną cywilizację wraz z jej internacjonalizmem i ponadnarodowością. Wśród niebezpieczeństw dostrzega anonimowość, niewyraźność i brak zakorzenienia. Jednocześnie uważa, że Europa jako wspólnota różnych narodów wytworzyła właśnie na fundamencie kategorii nacjonalności pewne systemy i schematy myślenia oraz działania, które obecnie umożliwiają cywilizacyjny postęp. Miejsce dziewiętnastowiecznej idei narodu (którą uważa za wynalazek europejski, nieprzystający do warunków amerykańskich) zajmują cywilizacje, które są względem narodów bardziej elementarne (Kozak, 1971, s. 146). Nacjonalność pozostaje $\mathrm{w}$ takim razie naczelną ideą $\mathrm{w}$ procesie internacjonalizacji świata. 
Kluczowym okresem krystalizowania się słoweńskiej świadomości narodowej (w tym konieczności posiadania własnego państwa) okazały się lata osiemdziesiąte XX wieku, zwłaszcza po śmierci Josipa Broza Tity, kiedy to w federacji jugosłowiańskiej zaczęły pojawiać się poważne pęknięcia. Słoweński program narodowy w tym czasie najwyraźniej przedstawiało środowisko skupione wokół czasopisma „Nova revija”, które zrzeszało ówczesną opozycję polityczną, występującą przeciw komunizmowi i opowiadającą się za demokracją parlamentarną. Wówczas też rozważaniom słoweńskich intelektualistów dążącym do uniezależnienia się od Jugosławii, towarzyszyło przekonanie o potrzebie powtórnego włączenia się Słowenii do tzw. Europy Środkowej.

Ogromny wkład w krytyczną refleksję nad ideą narodu, tożsamości i przyszłości Słoweńców wniósł w latach osiemdziesiątych i dziewięćdziesiątych XX wieku wybitny eseista i prozaik Drago Jančar. W tym też kontekście często jest zestawiany z innym, wcześniejszym autorem, w którego twórczości dochodziła do głosu idea narodu, czyli ze wspomnianym już Ivanem Cankarem. Obu autorów łączy - pomimo dzielącego ich działalność znacznego dystansu czasowego - potrzeba zdefiniowania statusu narodu słoweńskiego w dwóch przełomowych dla niego momentach: w okresie istnienia monarchii austro-węgierskiej i utworzenia Królestwa Serbów, Chorwatów i Słoweńców (jak to ma miejsce w przypadku Cankara) oraz w czasie istnienia Jugosławii i jej rozpadu (jak w przypadku Jančara). Oboje mieli także świadomość, że literatura nie może wpływać bezpośrednio na tok bieżącej polityki, jednak ma moralną moc, która wynika z faktu, że dokładnie odzwierciedla świat (Borovnik, 2015, s. 52).

Drago Jančar, który - jak sam przyznaje - sprzeciwiał się w okresie istnienia Jugosławii słoweńskiemu nacjonalizmowi, widzącemu „naród jako bojową organizację centralizmu demokratycznego, nie zaś jako zróżnicowaną wspólnotę kulturową" (Jančar, 1993, s. 90), swoją pogłębioną analizę sytuacji Słoweńców wybijających się na niezależność narodową i państwową zawarł w wydanym w 1989 roku tomie esejów pod symbolicznym tytułem Terra incognita. W jednym z nich podejmując refleksję nad dziejami słoweńskiego narodu, zauważa, że ich cechą charakterystyczną było uzależnienie od innych i wynikające stąd podziały. Wspominał w tym kontekście o rozłamie w XVI wieku na protestantów i katolików, w XIX na starosłoweńców i młodosłoweńców, a od 1943 roku na komunistów i tych, którzy znaleźli się w opozycji do ich rządów; wynikający z tych podziałów konflikt - jak zaznacza - w dużej mierze wpływa na aktualne życie polityczne w Słowenii (Jančar, 1993, s. 91). 
Ciekawe wnioski przynosi także inny tekst $\mathrm{z}$ tego tomu zatytułowany Identiteta. W eseju tym Jančar podkreśla - wobec niedostatecznie silnych czynników o charakterze historycznym - konstytutywną rolę słoweńskiej literatury i kultury w kształtowaniu całego narodu:

Tożsamość narodu słoweńskiego, tak jak niektórych innych środkowoeuropejskich, z braku realnych sił historyczno-politycznych potwierdzała się poprzez kulturę i literaturę. Wśród Słoweńców - głównie poprzez język, który stuleciami pielęgnowali oni, jak Żydzi swoją Torę (Jančar, 1993, s. 42).

Powołując się także na Milana Kunderę i jego słynny esej Tragedia Europy Srodkowej - który według niego był w Ljubljanie czytany, jakby napisał go Słoweniec - stwierdza, że małe narody są wspólnotami nietrwałymi, niestabilnymi, których istnienie zawsze poddawane jest w wątpliwość: „mały naród to ten, którego egzystencja w każdej chwili stoi pod znakiem zapytania; mały naród może zginąć i jest świadom tego faktu" (Jančar, 1993, s. 43). W dziejach narodu słoweńskiego dostrzega także los intelektualisty, który zamiast poświęcić się twórczemu dziełu, zmuszony jest wciąż zgłębiać kwestie przetrwania. Dlatego też dla Jančara istnienie każdego słoweńskiego intelektualisty oznacza „potwierdzanie w przeciwstawianiu” (Jančar, 1993, s. 43-44). „Pierwsza słoweńska książka była rezultatem protestantyzmu, sytuacja współczesnego pisarza słoweńskiego też jest "protestancka»" (Jančar, 1993, s. 44), zmuszony jest przecież do obrony własnego narodu i wolności. Tak samo jak narodowi słoweńskiemu niczego nigdy nie podarowano, tak również pisarz sam musi walczyć o prawo do pisania we własnym języku, a potem o prawo do wolności słowa.

W tytułowym eseju Terra incognita wskazuje $\mathrm{z}$ kolei na dwa podstawowe - i według niego kształtujące tożsamość małego narodu słoweńskiego - pojęcia, czyli represja i samobójstwo (Jančar, 1993, s. 51). W idyllicznym krajobrazie alpejskiego państwa, w którym odnotowano jeden z najmniejszych wskaźników analfabetyzmu, zakorzeniła się paradoksalnie - jak stwierdza - tragiczna tendencja do autodesktrukcji.

Współczesna, powstała już po ogłoszeniu niepodległej Słowenii, refleksja teoretyczna dotycząca narodu świadczy o niesłabnącym zainteresowaniu tą problematyką w słoweńskim środowisku naukowym; badacze i komentatorzy często koncentrują się przy tym na aspektach typowych dla tzw. małego narodu. Tine Hribar w monografii Slovenci kot nacija (1995) rozwinął tezę o narodzie, który jest dla niego po prostu trwałą wspólnotą o określonym imieniu. Słoweński naród współtworzą Słoweńcy, a więc naród jest czymś więcej niż sumą pojedynczych Słoweńców. Są oni ludźmi, którzy w większości są tego 
samego pochodzenia, mówią tym samym językiem i mieszkają na określonym terytorium (Hribar, 1995, s. 87).

To, co Słoweńców jako ludzi przemienia w naród - podkreśla Hribar - to narodowa świadomość, traktowana przez niego jako podstawa i wyraz kultury w najszerszym znaczeniu. Pod pojęciem kultury rozumie pielęgnowanie języka, literaturę, obyczaje, wiarę, szkolnictwo i naukę, a także etyczną kulturę jednostki oraz kulturę prawną i polityczną. Z dzisiejszej perspektywy niezależność narodu realizuje się w niezależności i trwałości państwa oraz w jego instytucjach. Zdaniem Hribara (jak również Ivana Grafenauera) naród, który zyskuje własne państwo, staje się nacją, czy też innymi słowy naród zyskuje świadomość tylko dzięki własnemu państwu: „Nacja jest to więc naród plus państwo. Naród ma świadomość narodową, ale narodową tożsamość zapewnia mu tylko państwo. Oczywiście, tylko i wyłącznie jego państwo” („Nacija je torej narod plus država. Narod ima narodno zavest, nacionalno samozavest pa mu daje šele država. Seveda samo in izključno njegova država“) (Hribar, 1995, s. 87). Według niego w dziejach świata można mówić tylko o narodach, które tworzą państwa.

Słoweńską samoświadomość zaczęto budować z chwilą plebiscytu na temat samodzielności i niezależności Słowenii w 1990 roku, a potwierdzono ją w ciągu następującego półrocza, kiedy Słoweńcy odparli agresję wojsk jugosłowiańskich. Z kształtowaniem się narodowej (samo)świadomości badacz ten wiąże nacjonalizm, który uważa za pojęcie w gruncie rzeczy neutralne, choć mogące także mieć wydźwięk pozytywny bądź negatywny. Hribar pisze: „Nacjonalizm - oznacza samoświadomość narodu jako podmiotu. Przede wszystkim jako podmiotu dla siebie samego, a następnie jako podmiotu w relacjach międzynarodowych” („Nacionalizem - pomeni samozavedanje naroda kot subjekta. Najprej kot subjekta samega sebe, potem pa tudi kot subjekta mednarodnih odnosov") (Hribar, 1995, s. 88). Jak zauważa, w przeszłości Słoweńcy posługiwali się nacjonalizmem obronnym (obrambni nacionalizem), obecnie zaś (tj. w połowie lat dziewięćdziesiątych XX wieku, czyli w okresie, gdy Słowenia zabiegała o międzynarodowe uznanie) - ekspresyjnym/wyrazistym (izrazni nacionalizem); zaznacza także, że w słoweńskiej tradycji nie pojawił się nacjonalizm agresywny (napadalen nacionalizem) (Hribar, 1995, s. 88-89).

Hribar podkreśla, że Słoweńcy, nie mając do początku lat dziewięćdziesiątych XX wieku własnego państwa i będąc przez ostatnie dziesięciolecia częścią federacji jugosłowiańskiej, znajdowali się na przednarodowej płaszczyźnie (na subnacionalni ravni) (Hribar, 1995, s. 89). W swoich rozważaniach na temat 
przyszłości Słoweńców analizuje ewentualny akces do jednoczącej się Europy, w której prym wiodą „państwa narodowe” (nacionalne države); dlatego proces zjednoczeniowy przebiega na poziomie transnacjonalnym. Słoweńcy nie mogą zatem - jego zdaniem - od przednarodowej płaszczyzny przejść bezpośrednio na poziom ponadnarodowy, gdyż zagroziłoby to nietrwałej i kształtującej się dopiero słoweńskiej tożsamości. Jednocząca się Europa tymczasem wymaga świadomego i suwerennego przekazania części swojej niezależności europejskim, ponadnarodowym instytucjom. Dlatego też proces kształtowania się świadomości narodowej Słoweńców powinien polegać najpierw na przejściu z płaszczyzny przednarodowej na narodową, potem zaś - z narodowej na ponadnarodową (Hribar, 1995, s. 90). Tylko w ten sposób naród słoweński stanie się równoprawnym partnerem dla Europy i podmiotem na arenie międzynarodowej; w przeciwnym razie Słoweńcy znajdą się na śmietnisku historii. Hribar posługuje się w tym kontekście takimi stwierdzeniami jak: „historyczny odpad; etniczny relikt, folklorystyczne zjawisko nie mające wpływu na swój los” („zgodovinski rejekt; etnični relikt, folklorna znamenitost brez vpliva na svojo usodo“) (Hribar, 1995, s. 90).

Podkreślając potrzebę bycia równoprawnym elementem (nie zaś subelementem) wspólnoty europejskiej, Tine Hribar uważa za paradoks, że Słoweńcy pragną zostać narodem w Heglowskim rozumieniu w czasach, kiedy era państw narodowych się kończy: „W paradoksalnym stwierdzeniu, że my Słoweńcy pragniemy stać się nacją, historycznym narodem w znaczeniu Heglowskim i to właśnie teraz, kiedy posłannictwo narodowych państw uległo wyczerpaniu, nie ma nic absurdalnego” („V paradoksu, da hočemo Slovenci postati nacija, zgodovinsko ljudstvo v heglovskem pomenu, prav zdaj, ko naj bi bilo poslanstvo nacionalnih držav že izčrpano, zato ni nič absurdnega") (Hribar, 1995, s. 91). Jego zdaniem jednak idea własnego suwerennego państwa pod koniec drugiego tysiąclecia jeszcze się nie zestarzała - europejska Wiosna Ludów miała miejsce w XIX wieku, a światowe odrodzenie narodowe czeka nas także w XXI stuleciu:

W okresie postmodernistycznego rozróżnienia między człowiekiem jako człowiekiem i człowiekiem jako podmiotem, między rzeczami jako rzeczami i rzeczami jako przedmiotami, między narodem jako narodem i narodem jako nacją (która zdoła jako Nacja wznieść się ponad naród) poddano jednocześnie w wątpliwość ideę suwerenności w znaczeniu bezwarunkowej, czyli nieskończonej bądź nieograniczonej specyficzności, na której jest (było) oparte klasyczne państwo narodowe.

V postmoderni dobi razločevanja med človekom kot človekom in človekom kot subjektom, med stvarmi kot stvarmi in stvarmi kot objekti, med narodom kot narodom in narodom kot nacijo (ki se utegne kot Nacija povzpeti nad narod) je obenem 
nastala vprašljiva ideja suverenosti v pomenu brezpogojne, se pravi brezmejne ali neomejene subjektivitete, na kateri je (bila) utemeljena klasična nacionalna država (Hribar, 1995, s. 91).

Odnosząc się do statusu Słoweńców w federacji jugosłowiańskiej Hribar zauważa, że opis losów języka słoweńskiego w tym przypadku jest także metaforą narodu słoweńskiego. Dodaje przy tym, że naród słoweński jako pełnoprawny podmiot $\mathrm{w}$ stosunkach międzynarodowych powinien współuczestniczyć w kształtowaniu europejskiej wspólnoty, do której droga wiedzie poprzez dezintegrację Jugosławii ,jako bałkańskiego fraktala Związku Radzieckiego” („kot balkanskega fraktala Sovjetske zveze“) (Hribar, 1995, s. 93).

Janko Kos w książce Duhovna zgodovina Slovencev (1996) przypomina, że starsza generacja słoweńskich badaczy w pojęciu nacija widziała synonim tradycyjnego określenia narod, natomiast młodsi badacze dostrzegali dystynkcję w obu pojęciach, która była istotna dla rozumienia statusu Słoweńców w ostatnim czasie (Kos, 1996, s. 14). By pojąć właśnie ów sens duchowego położenia narodu słoweńskiego w historii, Kos podejmuje się dokładniejszego rozgraniczenia pojęć wspólnota plemienna, lud, naród i nacja (plemenska skupnost, ljudstvo, narod i nacija), które traktuje jako cztery etapy życia wspólnotowego Słoweńców od kiedy - jak mówi - zostali Słoweńcami. Pierwszy etap przypada na okres 740-962, kiedy Słoweńcy stanowili wspólnotę plemienną bądź wchodzili w skład kilku takich zbiorowości - mało jest jednak wystarczających świadectw historycznych w tym zakresie. Nie można mimo to twierdzić, że członkami tej zbiorowości byli Karantanie. Od X wieku ludność zamieszkująca ziemie słoweńskie rozwija się w zbiorowość, którą można określić mianem ljudstva. Słoweńcy w okresie późnego średniowiecza stanowili ljudstvo w tym znaczeniu, że różnili się od innych, niesłowiańskich mieszkańców tego terytorium, stanowiąc jednocześnie wspólnotę ludzi spójną pod względem polityczno-społecznym i kulturowym, która jest homogeniczna i zależna od warstw wyższych, niemówiących po słoweńsku - podczas gdy ci nosili określenie natio (Kos, 1996, s. 14-15). Tak pojęte ljudstvo zaczęło od XVI wieku kształtować się w naród - proces ten był jednak złożony i długotrwały (zakończył się na przełomie XIX i XX wieku). Różnica między narodem a ludem jest oczywista, gdyż naród jest wspólnotą, która sama w sobie jest zróżnicowana, heterogeniczna, zhierarchizowana, co znaczy, że składa się z niższych i wyższych warstw, często też ma wyraźnie wykrystalizowane elity i pokrewne warstwy społeczne. To, co łączy poszczególne warstwy narodu to język literacki, wspólna kultura narodowa, społeczna organizacja i polityka, oparta na tym języku. Wraz z ukształtowaniem się Słoweńców jako 
narodu, ljudstvo nie zanikło, tylko zostało wchłonięte przez naród jako jego część, ale również jako jego wewnętrzna opozycja (zgodnie z myślą Cankara z $1907 \mathrm{roku}$ ). Zakładała ona, że lud ponownie zdobędzie przewagę nad narodem i w tym sensie wykazywała związek z myślą marksistowską, co zapewne wpłynęło na postrzeganie relacji między ludem a narodem w słoweńskich teoriach. Podobnie problematycznie wygląda sprawa rozróżnienia pomiędzy narodem a nacją. Słoweńcy weszli w etap przechodzenia od narodu do nacji w latach osiemdziesiątych XX wieku. Pojęcie nacji - jak zaznacza Kos - można porównać z zachodnioeuropejskim i amerykańskim pojęcie nation. Oznacza ono wspólnotę, która jest nośnikiem państwowości, uznaną przez inne nacje. Gdy naród zostaje nacją, zdobywa ona właściwości, które przekraczają istnienie narodu jako narodu, w szczególności to, że nacja uznaje za swoich równorzędnych członków także reprezentantów innych narodowości. To oczywiście nie znaczy, że naród rozpływa się w nacji - nacja, która powstała na fundamencie narodu i jego prawa do samookreślenia, jest ściśle z nim związana i z niego czerpie swoją legitymizację (Kos, 1996, s. 16-17).

Zdaniem Janka Kosa pojęcie narod jest przykładem wspólnotowego podmiotu, któremu przypadają jednostki w ten sposób, że nabywają właściwości, których by nie posiadali poza tą zbiorowością. Od razu jednak zaznacza, że użycie tego pojęcia w języku słoweńskim, podobnie jak innych pokrewnych, to znaczny plemenska skupnost, ljudstvo i nacija wykazuje duże wahania, nieostrość i nieokreśloność, co wynikało z ich roli w społeczno-politycznym rozwoju Słoweńców. Najbardziej pierwotnym z nich jest pojęcie ljudstvo, do którego około 1800 roku, a więc u progu oświecenia i romantyzmu, dołączyło pojęcie narod - początkowo nie rozróżniane i traktowane synonimicznie.

Wyjątkowość historycznego rozwoju Słoweńców uwidacznia się również $\mathrm{w}$ procesie kształtowania ljudstva, naroda i naciji jako trzech kolejnych historycznych zbiorowości, w których grupowali się jako Słoweńcy - w ten sposób, że wcześniejsza faza rozwoju była wchłaniana przez następną. Tak więc najpierw ljudstvo w narodzie, a potem narod w naciji: „Powołując się na Hegla można zatem stwierdzić, że jedna [faza rozwoju - D.K.] przechodzi w drugą, ale jednocześnie zyskuje także nową formę” („Po Heglu bi se smelo trditi, da se ena v drugi sicer odpravljajo, vendar hkrati tudi v novi obliki ohranjajo") (Kos, 1996, s. 18).

W nawiązaniu do rozważań Cankara i Jančara na temat narodu i roli literatury dla jego kształtu słoweński eseista i krytyk literacki Mitja Čander w swoim artykule z 2004 roku Między wieżą z kości słoniowej a ulicą. O słoweńskiej kulturze 
$w$ czasach transformacji stawia istotne pytanie, dotyczące tego, co naprawdę słoweńskiego jest w literaturze słoweńskiej. Odpowiedź, którą proponuje stanowi jednocześnie diagnozę stanu małego narodu, jakim są Słoweńcy: „Los narodu miał się do niedawna odzwierciedlać w łańcuchu sytuacji stresowych, naród słoweński miał być gatunkiem zagrożonym, zepchniętym na margines, a jednocześnie zahartowanym w walce o przetrwanie" (Čander, 2004, s. 10).

Obecnie narodowy dyskurs historyczny w Słowenii ${ }^{6}$ koncentruje się wokół dwóch - w dużej mierze wyobrażonych - koncepcji dziejów i etnogenezy Słoweńców. Pierwsza z nich, autochtoniczna, za ich przodków uznaje Wenetów, którzy zasiedlali znaczne obszary Europy; druga zaś, teoria kontynuacji, mówi o Słoweńcach jako potomkach Karantan, zasiedlających tereny zamieszkiwane dziś m.in. przez Słoweńców już od VII wieku. Znaczna jednak część słoweńskich historyków odrzuca te koncepcje, uważając je za mało przekonujące z powodu znikomej liczby źródeł historycznych (np. Peter Štih). Niektórzy jak Aleš Žužek uważają, że choć nie wszyscy należący do narodu słoweńskiego są bezpośrednimi potomkami Karantan i Karnów, to jednak można uznać, iż „współcześni karynccy Słoweńcy są prawdopodobnie bezpośrednimi potomkami wczesnośredniowiecznych Karantan. Karynccy Słoweńcy są zatem - niezależnie od tego w którym państwie mieszkają - integralną częścią narodu słoweńskiego” („današnji koroški Slovenci so zanesljivo neposredni potomci zgodnjesrednjeveških Karantancev. Koroški Slovenci pa so - ne glede na to, v kateri državi živijo - integralen del slovenskega naroda") (Žužek, 2006, s. 42). Polemizując z Peterem Štihem, Žužek zaznacza, że wszystkie symbole związane z historią Karantanii są także uważane za słoweńskie narodowe symbole (w tym, oczywiście, tzw. knežji kamen ${ }^{7}$ ). Jeśliby bowiem, twierdzi Žužek, ten zabytek nie był uznawany za słoweński narodowy symbol, wtedy oznaczałoby, że karynccy Słoweńcy nie stanowią części słoweńskiego narodu. Opowiadając się za teorią kontynuacji, proponuje jednak uzupełnienie tej koncepcji o dwa osobne procesy historyczne. Pierwszy z nich obejmuje rozpoczętą w VI wieku słoweńską etnogenezę, której rezultatem było wytworzenie pod względem językowym grupy słowiańskiej znacznie różniącej się od Słowian bałkańskich.

6 Za wykładnię tego dyskursu historycznego można uznać na przykład wydaną w 2009 roku książkę Petera Štiha, Vaska Simoniti i Petera Vodopiveca Slovenska zgodovina: družba-politika-kultura.

7 Więcej na temat tego ważnego dla słoweńskiej tożsamości narodowej zabytku, będącego ostatnio także przedmiotem sporu z Austrią, zob. Grafenauer (1995, s. 61-65); Žužek (2006, s. 41-42). 
Drugi zaś z procesów, odnosi się do narodowego uświadamiania Słoweńców w XIX wieku, który doprowadził do powstania politycznie świadomego narodu słoweńskiego (Mandek, 2011, s. 102-104)

Idea narodu na ziemiach słoweńskich pod wpływem różnorodnych czynników i okoliczności zyskała interesujący i złożony charakter. Graniczne położenie w sensie politycznym i kulturowym, wielowiekowe dążenia do stworzenia własnego państwa oraz silny do dziś regionalizm ukształtował ideę, która odegrała znaczącą rolę $\mathrm{w}$ formowaniu także innych idei i koncepcji wśród Słoweńców.

\section{BIBLIOGRAFIA:}

Babić, J. (2008). Johann Gottfried Herder i njegove ideje u južnoslavenskome književnom i kulturno-političkom kontekstu 19. stoljeća. Osijek: Sveučilište Josipa Jurja Strossmayera u Osijeku, Filozofski fakultet.

Barbarič, Š. (1978). Herder in der slowenischen Literatur. W: G. Ziegengeist (Red.), Johann Gottfried Herder: Zur Herder-Rezeption in Ost- und Südosteuropa (ss. 117-124). Berlin: Akademie-Verlag.

Bernik, F. (2011). Primož Trubar in identiteta Slovencev. W: K. Ahačič \& P. Testen, Med središč in obrobji: V počastitev 500. obletnice rojstva Primoža Trubarja (ss. 21-28). Ljubljana: Založba ZRC, Institut za kulturno zgodovino ZRC SAZU.

Bohinec, V. (1975). Peter Kozler in prvi zemljevid slovenskega ozemlja. Ljubljana: Cankarjeva založba.

Borovnik, S. (2015). Slovenski narod in država v izbranih esejih Draga Jančarja. W: H. Tivadar (Red.), 51. seminar slovenskega jezika, literature in kulture: Država in narod v slovenskem jeziku, literaturi in kulturi (ss. 51-58). Ljubljana: Znanstvena založba Filozofske fakultete.

Bučar, F. (2009). Slovenci in pripadnost: Slovenski narod po rojstvu države. Radovljica: Didakta.

Cankar, I. (1921). Slovensko ljudstvo in slovenska kultura. Dom in svet, (7/9), 163-166, 213-216.

Čander, M. (2004). Między wieżą z kości słoniowej a ulicą: O słoweńskiej kulturze w czasach transformacji. (W. Karkos, Tłum.). Opcje: Kwartalnik kulturalny, (1/2), 6-13.

Grafenauer, B. (1995). Ustoličevanje koroških vojvod, gradnja slovnskega državnega mita in vpliv na oblikovanje slovenskega naroda v 19. stoletju. W: B. Grafenauer (Red.), Slovenci in država: Zbornik prispevkov z znanstvenega posveta na SAZU (od 9. do 11. novembra 1994) (ss. 61-66). Ljubljana: Slovenska akademija znanosti in umetnosti.

Grdina, I. (2011). Pripadnosti in identitete med preteklostjo in vizijami prihodnosti. W: K. Ahačič \& P. Testen (Red.), Med središči in obrobji: V počastitev 500. obletnice rojstva Primoža Trubarja (ss. 9-20). Ljubljana: Založba ZRC, Institut za kulturno zgodovino ZRC SAZU. 
Damian Kubik Kształtowanie się idei narodu na ziemiach słoweńskich-zarys wybranych ...

Hribar, T. (1995). Slovenci kot nacija, Soočanja s sodobniki. Ljubljana: Etnost.

Jančar, D. (1993). Terra incognita. (J. Pomorska, Tłum.). Warszawa: Niezależna Oficyna Wydawnicza.

Kardelj, E. (1984). Socialistična zveza delovnega ljudstva. Ljubljana: Državna založba Slovenije.

Kerševan, M. (2011). „Cerkev Božja slovenskega jezika“ - vloga jezika v reformaciji in modernem nacionalizmu. W: K. Ahačič \& P. Testen (Red.), Med središči in obrobji: V počastitev 500. obletnice rojstva Primoža Trubarja (ss. 83-98). Ljubljana: Založba ZRC, Institut za kulturno zgodovino ZRC SAZU.

Kidrič, F. (1938). Zgodovina slovenskega slovstva od začetkov do Zoisove smrti: razvoj, obseg in cena pismenstva književnosti in literature. Ljubljana: Slovenska matica.

Kmecl, M. (2005). Kratka kulturna zgodovina Slovencev. Ljubljana: Slovenski PEN.

Kos, J. (1996). Duhovna zgodovina Slovencev. Ljubljana: Slovenska Matica.

Kosi, J. (2008). O pogojenosti „nacionalne zgodovine“ $\mathrm{z}$ nadnacionalnim - proces formiranja slovenskega naroda kot primer. W: N. Troha, M. Šorn, \& B. Balkovec (Red.), Evropski vplivi na slovensko družbo (ss. 93-101). Ljubljana: Zveza zgodovinskih društev Slovenije.

Kozak, P. (1971). Peter Klepec v Ameriki. Maribor: Obzorja.

Mandek, D. (2011). Na mejah nacije: Teorije in prakse nacionalizma. Ljubljana: Znanstvena založba Filozofske fakultete.

Matvejević, P. (1986). Otvorena pisma - moralne vježbe. Zagreb: vlastita naklada.

Melik, V. (1995). Slovenski državnopravni programi 1848-1918. W: B. Grafenauer (Red.), Slovenci in država: Zbornik prispevkov z znanstvenega posveta na SAZU (od 9. do 11. novembra 1994) (ss. 67-72). Ljubljana: Slovenska akademija znanosti in umetnosti.

Orožen, M. (1986-1987). Primož Trubar in razvoj slovenskega književnega besedišča v jeziku protestanstskih piscev: Ob 400-letnici smrti Primoža Trubarja. Jezik in slovstvo, 32(2/3), 36-47.

Prijatelj, I. (1937). Borba za individualnost slovenskega književnega jezika v letih 1848-1857. Ljubljana: Slavistično društvo.

Samar Brenčič, N. (2008). Primož Trubar in njegovo mesto v verskih razmerah slovenskega etničnega prostora 16. stoletja. Ljubljana: samozal.

Štih, P. (2005). Nacionalizem kot zgodovinski nesporazum. W: P. J. Geary, Mit narodov - srednjeveški izvori Evrope (ss. 221-237). Ljubljana: Studia Humanitatis.

Urbančič, I. (1979). Elementi za razvitje vprašanja naroda na Slovenskem. Problemi, 59, 83-92.

Vidmar, J. (1932). Kulturni problem slovenstva. Ljubljana: Tiskovna zadruga.

Žužek, A. (2006). Kdo se boji Knežnega kamna? Ampak: Mesečnik za kulturo, politiko in gospodarstvo, 7(8/9), 41-42. 


\section{Kształtowanie się idei narodu na ziemiach słoweńskich - zarys wybranych problemów}

Artykuł podsumowuje najistotniejsze etapy kształtowania się narodu słoweńskiego począwszy od XVI wieku aż do czasów współczesnych. Szczególną uwagę poświęcono analizie źródeł historycznych i wybranych studiów naukowych.

Słowa kluczowe: naród, tożsamość narodowa, Słowenia, Słoweńcy

\section{The Formation of the Idea of the Nation in the Slovene Lands - an Outline of Selected Problems}

The paper summarises the most significant phases of formation of the Slovenian nation from the sixteenth century to the present. Special attention is paid to the analysis of historical sources and selected scientific studies.

Keywords: nation, national identity, Slovenia, Slovenes

\section{Notka o autorze}

Damian Kubik (d.kubik@uj.edu.pl) - slawista i polonista (komparatysta), doktor, asystent w Instytucie Filologii Słowiańskiej Uniwersytetu Jagiellońskiego, członek zespołu grantowego w Instytucie Slawistyki Polskiej Akademii Nauk (od 2014). Autor książki Południowosłowiańska „kultura wyobrażona”. Projekt Mickiewiczowski a dziewiętnastowieczne dyskursy kulturowe w Serbii $i$ Chorwacji (2015) oraz wielu artykułów z zakresu historii literatur południowosłowiańskich. Zainteresowania naukowe: kultura chorwacka i serbska, historia idei na Bałkanach, historia slawistyki (w XIX wieku), polski romantyzm i Adam Mickiewicz. 
Damian Kubik, PhD (d.kubik@uj.edu.pl) - Slavist and Polish philologist (comparatist), Assistant at the Institute of Slavic Philology, Jagiellonian University, member of research team at the Institute of Slavic Studies, Polish Academy of Sciences (since 2014). Author of the book Poludniowostowiańska „kultura wyobrażona". Projekt Mickiewiczowski a dziewiętnastowieczne dyskursy kulturowe $w$ Serbii i Chorwacji (2015) and many articles on South-Slavic literatures. Research interests: Croatian and Serbian culture, history of ideas in the Balkans, history of Slavic philology (in the nineteenth century), Polish Romanticism and Adam Mickiewicz. 